\title{
IN DEFENCE OF ANTHROPOMORPHIC THEISM
}

\author{
PETER FORREST
}

University of New England

\begin{abstract}
I reply to seven objections to anthropomorphic theism: (1) That anthropomorphic theism is idolatrous. In reply I rely on the concept/conception distinction. (2) That faith requires certainty. In reply I argue that full belief may be based on probable inference. (3) That the truly infinite is incomprehensible. In reply I distinguish two senses of knowing what you mean. (4) 'You Kant say that!' In reply I distinguish shallow from deep Kantianism. (5) 'Shall Old Aquinas be forgot?' In reply I discuss the simplicity of God. (6) What those garrulous mystics say about the ineffable. In reply I argue that mystics should be anthropomorphites. (7) Anti-theodicy. In reply I distinguish the community of all agents from the community of finite frail agents.
\end{abstract}

By anthropomorphic theism I do not mean the thesis that God has a humanoid body, but rather that either God as a whole or the Divine Persons taken individually are literally agents and literally have knowledge and power, and literally have a certain kind of character, being loving or in some other fashion morally good. In academic circles that conception of God is often dismissed as outmoded and naive. In this paper I consider and reply to seven objections to anthropomorphic theism.

My monsters are, in order of the increasingly bizarre, Thomists, Wittgensteinian philosophers of religion - e.g. Dewi Phillips (2005) and Andrew Gleeson (2010) - and Continental philosophers of religion e.g. John Caputo (1997) and Nick Trakakis (2008). Philosophy is like a horror movie, or one of Descartes' dreams. Once you form a clear and distinct idea of the monster it ceases to be frightening and becomes merely comical - a dyspeptic dinosaur or a grumpy octopus - and the only decision is whether to destroy or domesticate. It is the barely glimpsed and ever changing we-know-not-what that scares us. So for 
any proposition whatever to attribute it to, say, Derrida, is to invite the criticism of having misunderstood.

Here are the seven objections, with my replies.

\section{THAT ANTHROPOMORPHIC THEISM IS IDOLATROUS}

The claim that anthropomorphic theism is idolatrous is, I suspect, based upon the mistaken position that God's greatness is comparative, and so God is praised by a misplaced humility that exaggerates the gap between us and God. But that is just my suspicion. To defeat the charge of idolatry, I need to say something about differing conceptions of God and something about idolatry.

For present purposes I take our concept (definition) of God as that which is worthy of worship, where to worship something is to have an attitude of unconditional trust and obedience. Because this is an evaluative concept we may make the concept/conception distinction (Gaillie 1956, Rawls 1971), keeping the verb 'conceive of' as roughly synonymous with 'describe,' but without the connotation that description is contrasted with evaluation. The conception, on the other hand, is the worshipper's conceiving of that in virtue of which the definition holds. Unlike a pure description it might itself be partly an evaluation, so long as it provides more detail than the definition itself. Thus a conception of God might include God's moral goodness, or it might, instead, describe that in virtue of which God is morally good, say God's being loving. Given that the concept of God is that which is (most) worthy of worship, the conception of God must, however, exclude beliefs that are not conducive to the worship. Thus someone could believe in divine simplicity without divine simplicity being part of the conception of God, because, the person believes, it is not part of that in virtue of which God is worthy of worship.

There may be some whose conception of God is of that which is not conceivable in positive terms. ${ }^{1}$ Call this the apophatic conception, and

${ }^{1}$ The positive/negative distinction for predicates is awkward. For some predicates might be neither, (e.g. 'either $\mathrm{x}$ is not an agent or $\mathrm{x}$ is loving') and some are hard to classify as positive, negative, or neither, notably ' $\mathrm{x}$ is simple.' For present purposes I characterise a predicate Fx as positive if either it is itself a natural kind term or for every natural kind 
those who have it moderate apophats. More plausible is the position of the radical apophats, who deny the propriety of any conception of God. That is, although they may have various beliefs about God they deny that anything can be said about that in virtue of which God is worthy of worship - God just is worshipful, with nothing more to be said. Others of us - anthropomorphites - have a much more definite conception of God as a morally good agent of unlimited knowledge and power. ${ }^{2}$

To worship God is to risk idolatry, namely worshipping something unworthy of worship, because either it is intrinsically not worth worshipping or because it is less worthy than something else. Now, worship takes an intentional object. That is 'S worships X' does not entail that $\mathrm{X}$ exists, or even that $\mathrm{X}$ is possible. So the phrase 'something else' is ambiguous. It could mean something actual, something possible but not actual, or even something impossible. (Note that because worship takes an intentional object I talk of God as an object of worship. This does not imply that God is an object in any other sense.)

I now argue that we anthropomorphites need not be concerned with the claim that an impossibility is worthier of worship than the anthropomorphic God. I note, in passing, that those such as perhaps Caputo's Derrida, or perhaps Caputo himself, who are said to worship something they believe impossible might be interpreted in various ways, for instance as worshipping that for which there are no conceivable grounds for Its possibility (Caputo 1997). Again, they might be worshipping something with contrary properties, for instance justice and mercy defined in such a way as to be inconsistent. Some dialethists such as Graham Priest hold that there are things that exist with contradictory properties, but these are actual and so possible (Priest 1996). ${ }^{3}$

We should ignore impossible objects of worship because we should restrict the concept of idolatry to something that is reasonably prohibited.

$\mathrm{K}$, the Ks that are $\mathrm{F}$ is a natural sub-kind. A negative predicate is one whose negation is positive. Using this criterion, ' $\mathrm{x}$ is simple' is positive.

${ }^{2}$ Or, in my conception, an agent whose only limitations are freely chosen (Forrest 2007). But this variation on unlimited knowledge and power need not here concern us.

${ }^{3}$ In response to Priest, Derrida said 'When I contradict myself I do not contradict myself.' So presumably Derrida does not believe that 'the other' is an existing but impossible object. If he did he could scarcely call himself an atheist. I also note Bob Meyer who, as far as I know, genuinely believed in a God with inconsistent properties. I owe to him the example of God's justice and mercy. 
Alternatively, if you insist it is idolatry to worship a being than which something impossible is worthier of worship then we should distinguish between good and bad idolatry, where good idolatry is not reasonably prohibited and anthropomorphites may agree they are idolaters but of the good kind.

There are two reasons why it is not reasonable to prohibit what I shall now call pseudo-idolatry, namely the 'idolatry' of worshipping something less worthy than an impossible object. The first is that nonidolatry (and hence the destruction of idols) is not an end in itself, but a means to the end of proper worship. Now, I say it is unreasonable to require ignorance of its object as a condition for worship. ${ }^{4}$ Hence the prohibition of pseudo-idolatry is reasonable only if it is reasonable to worship the impossible knowing it to be so. But although many people have worshipped the impossible, to worship something is to worship It as existing, so it is incoherent to worship something you believe to be impossible.

The second reason for ignoring pseudo-idolatry is that we can explain why idolatry is prohibited. For worship is unconditional trust and obedience. Now conditional trust etc. is trust etc. that would be withheld if circumstances were different. And when we compare the actual with a hypothetical situation we always assume the hypothetical is possible, unless it is explicitly stated to be impossible. ${ }^{5}$ Hence the most that unconditional trust etc. requires is that there be no possibility of something more worthy of worship. Hence pseudo-idolatry is not bad idolatry.

I concede, however, that the properly worshipful must not just be that than which none worthier of worship exists but must be that than which none worthier of worship is possible. ${ }^{6}$ Moderate apophats might be interpreted as accusing anthropomorphites of idolatry on the grounds that the apophatic conception is of a greater being than the

${ }^{4}$ Worship involves trust, and willingness to trust even when it is risky is a virtue. So too much knowledge of the object of worship conflicts with the exercise of a virtue. But that does not show that ignorance is required for worship.

${ }^{5}$ For example, 'I believe time travel to be impossible because if it were possible then the time traveller would be fated to behave in a certain way'.

${ }^{6}$ Unless epistemic possibility is explicitly being considered, possibility is always interpreted as metaphysical possibility in this paper. 
latter. They may join radical apophats in accusing anthropomorphites of idolatry on the grounds that nothing we can conceive of would be worth worshipping, even if nothing worthier were possible. Initially I shall interpret the continental philosopher of religion John Caputo (1995) as making this accusation, with which Nick Trakakis (2008) sympathizes.

As a preliminary, I say that the fear of a moderate risk of idolatry should not make us refrain from worship. That would be an instance of tutiorism, the unwillingness to risk performing a sinful act, even for an excellent reason. We should reject tutiorism because of its capacity to interfere with love of self, of neighbor and of God. In particular, we should take a moderate risk of idolatry for the sake of worshipping God.

A reasonable fear of idolatry will, therefore, give careful consideration to various conceptions of God, to see which, if any, result in idolatry. I accuse moderate apophats of idolatry because their conception does not mention that God is good in the moral sense, and we should give unconditional trust and obedience only to the morally good. In this connection I note but regret the human tendency to consider the mysterious worshipful.

Moderate apophats might respond in one of two ways. One is to assert that God is morally good in a way we cannot conceive of. This coheres poorly with the revelation that God is loving, because being loving is a way of being morally good we can conceive of. In any case, this response is incompatible with the apophatic conception, which is that there is no further detail to be given when conceiving of that in virtue of which God is worthy of worship other than God's inconceivability. To say we can go one step further before we cease to be able to conceive is to reject the apophatic conception. The other moderate apophatic response is to deny that God is morally good but instead to say that moral goodness is predicated by analogy of God. ${ }^{7}$ I shall discuss analogy below- here it suffices to challenge the apophat to explain just how we can truly apply the predicate 'morally good' by analogy without us being therefore able to conceive of God as 'analogically morally good.'

Far from the moderate apophat having a more worship-worthy conception of God than the anthropomorphite there are reasons, then,

${ }^{7}$ If Wolterstorff (2010) is right in his interpretation of Aquinas theory of analogy, Aquinas asserts that God is morally good even though goodness is predicated by analogy. 
why the God of the moderate apophats might be unworthy of worship even if there was no better. Maybe, though, this is to condemn a straw apophat, because actual ones are all radical. Coming closer, I suspect, to the positions of Phillips (2005) and Caputo (1997), I argue against apophats that the anthropomorphite conception is the best we have. For, I say, there is nothing possible we humans can conceive of that is more splendid than a morally good agent, whether human or divine. And if we add that this agent is unlimited in power and knowledge then it is a proper object of unconditional trust, love and obedience, and is that than which nothing worthier of worship can be conceived. Perhaps apophats will complain that it is possible there is something greater than anything we can conceive of. I agree that it is epistemically possible - we do not know that it is not the case. But to refuse to worship the anthropomorphic God because we do not know there is no greater is the tutiorism I have rejected - a bit like not having sexual relations with someone who was adopted as a child, because you are not certain the person is not your half-sibling. There is, however, no reason whatever to believe in the metaphysical (as opposed to epistemic) possibility of something worthier of worship than the anthropomorphic God. How could we, unless we can form a definite conception?

I draw the provisional conclusion that unlike the apophatic conception the anthropomorphic is not genuinely threatened with being idolatrous. There is more, though, to the accusation of idolatry. For my provisional interpretation of that accusation by Continental philosophers of religion is not the only one. It is also plausible that anthropomorphites, and analytic philosophers generally, are accused of worshipping a mere construct in place of God. Here I have a problem: I know what I mean by the word 'construct' but I suspect those who use that word freely do not. I shall now explain what I mean in order to show that an unlimited agent is not a construct in this sense.

I follow Meinongians to the limited extent of granting that the quantifier 'some' does not have an existential implication. So some things exist and some things don't. There are some predicates $\mathrm{X}$, notably 'exists' itself, such that the proposition that some $\mathrm{Y}$ is $\mathrm{X}$ entails that there exists a Y. Call these existential predicates. I assume that there is a recognisable class of mental attitude predicates, none of which are existential. I take it, then, that we recognise as standard the use in which atheists grant that 
theists worship something even though, they say, we worship something that does not exist.

By a construct I mean something of which a mental attitude predicate holds essentially. Now the word 'essential' derives from a precise enough piece of medieval philosophical jargon, but it has come to have several meanings. For present purposes the relevant sense is that the mental attitude predicate is part of the conception of God. For example, if you had a conception of God as actually worshipped then God would be a construct. If we are going to treat constructs as idols then this characterisation of a construct should be refined so as to exclude disjunctive, conditional and negative predicates, and so as to treat every mental attitude predicate as a disjunction of the reflexive and nonreflexive case. For instance, something does not have to be possible to be inconceivable; for often we assume that inconceivable things such as (Euclidean) square circles cannot exist. But because 'inconceivable' is negative the inconceivable God is not a construct. Nor is Its worship in itself idolatrous. What is idolatrous is the entailed omission of divine goodness.

It is worth checking that paradigmatic social constructions do turn out to be constructs as defined. A coin for instance consists of an object, typically a metal disc, of which the predicate 'widely believed to have a designated monetary value' is part of our concept. That predicate is non-existential because it could be the case that the half-cent coin is widely believed to have a designated monetary value even though there never were any such coins.

Another paradigm of a construct is a promise. A promise is not just a form of words but a form of words conventionally understood as binding. The property of being conventionally understood as binding could well hold of some famous but mythical historical promise.

If it were part of our conception of God that It is that than which no greater is conceived of by us, then this God would a construct, because we can conceive of things that do not exist. And I grant that worshipping a construct is idolatry because it is absurd to put unconditional trust and obedience in something that depends on us.

What these examples show is that genuine fear of idolatry should motivate an exercise in analytic philosophy, namely investigating which conceptions of God imply, in perhaps subtle ways that God depends on 
us. The conception of God as an agent without any limitations to power and knowledge is not a construct and worshipping such a God is not idolatrous, unless there is some possible thing worthier of worship, which I have denied.

\section{THAT FAITH REQUIRES CERTAINTY}

Although explanatorypowerisnot partoftheanthropomorphicconception of God many have that conception because, they say, anthropomorphic theism provides the best ultimate explanation of things. ${ }^{8}$

This makes theism a metaphysical hypothesis set up as a rival to naturalism, and makes theism the content of a 'reasonable faith.' There is, the objection continues, no way in which the belief that something is the best hypothesis is compatible with the sort of passionate commitment that is faith (Phillips 1995, ch 1). Suppose that the argument for the anthropomorphic God has some precise probability, say 75\%. It is then unwarranted to have anything other than a degree of credence equal to that probability, namely $75 \%$. This illustrates the dilemma that, in the absence of strict proof of God's existence, we must either settle for a degree of credence less than full belief, or adopt a passionate commitment to a God who is experienced in our lives. The former is judged inadequate; the latter is subjective in the sense that it is arrived at by each individual for him or herself.

First I note the Protestant background of this complaint, based as it is on the supposed importance of the individual's act of faith. ${ }^{9}$ Next, I note the curious asceticism of those who want to make their faith difficult. But even given that background we may respond by denying the wisdom of proportioning belief to the evidence, and with Newman (1903) granting that it is warranted to have full belief ('assent') in that which, considered

${ }^{8}$ My own preferred speculation is slightly different. I speculate that the ultimate explanation is an unlimited agency without any character. It would be idolatrous to worship this God. But, I speculate, It becomes loving and hence worshipful.

${ }^{9}$ I take Kierkegaard as an especially articulate and self-aware proponent of this sort of critique of reasonable faith, especially when it concerned the Incarnation. The criticism being considered is no longer specifically Protestant, because of the individualistic character of 'Western' culture. 
as a hypothesis, is supported only by a probable inference. This response may be made more technical by denying that there is a precise probability for the case for anthropomorphic theism. We may then follow Kyburg in treating precise probabilities as a first approximation only, with a better one obtained by measuring probabilities as intervals, as it might be $75 \%$ $\pm \mathrm{K} \%$ for some $\mathrm{K}$ (Kyburg 1974). To be sure, the precision in the value of $\mathrm{K}$ is still somewhat counterintuitive but Kyburg's theory of probabilities is a step in the direction of plausibility. Suppose, for instance, that the case for the anthropomorphic God has probability $75 \% \pm 25 \%$, that is, the interval from $50 \%$ to $100 \%$. Then rationality does not specify any degree of belief in that range. ${ }^{10}$ Hence a passionate commitment could result in full belief. ${ }^{11}$

\section{THAT THE TRULY INFINITE IS INCOMPREHENSIBLE}

Some might reject anthropomorphic theism on the grounds that I claim to know what I am talking about, contrary to the tradition of caution in talking about God. In a sense of course I claim to know what I am talking about, but there is also a sense in which I make no such claim.

Sometimes when we speak we feel confident that we know what we mean. This typically happens when we can clearly imagine what it would be like for what we say to be true, and what it would be like for what we say to be false. There are many ways, however, in which we can talk truthfully of something without this confidence. In those cases we might well say we do not know what we are talking about. One source of examples of this is mathematics. I find it interesting that spheres of different dimensions have quite different characteristics. But I cannot imagine hyper-spheres nor can I follow most of the proofs. Another source of examples is provided by the layperson's use of natural kind terms. Someone might say a lot of accurate things about Uranium 235

${ }^{10}$ In the absence of any emotion we might well tend to have degrees of belief near the middle of the range, say within $10 \%$ of $75 \%$. But to insist on this is to go beyond the argument, which is here assumed to have a probability measured as an interval of $50 \%$ width not one of $20 \%$.

${ }^{11}$ For a recent discussion of the conditions under which passional belief is warranted, see Bishop (2007). 
and Uranium 238 without understanding even that their nuclei have different number of neutrons. But an example that I think may be more relevant to talking about God is that of a red/green colour-blind person, who can distinguish yellow from blue and asserts that red and green are colours. The colour-blind person can speak about colours and has an imaginative grasp of the yellow/blue contrast, but no imaginative grasp of the red/green contrast.

Now consider the assertion that the Primordial God is an agent, but one without any limitations. Opponents of my anthropomorphic theism may be supposing that I feel the same confidence about knowing what I am talking about when I say God is an agent as when I say I am an agent but deny that Christmas trees are. I do not.

Our capacity to talk about things without knowing what we are talking about should be taken as a datum for philosophy of language not a controversial thesis. Hence it supports those theories of reference that explain this datum. Thus on the Putnam-Kripke causal theory of reference we can apply a natural kind term by referring to the kind, without any knowledge of the kind such as a scientist has (Kripke 1980, Putnam 1973; see also Bird and Tobin 2010). But in many cases we can pick out a kind, as the most natural kind exemplified by the paradigms and not exemplified by a contrasting group of anti-paradigms. It's like a treaty between two nineteenth century European countries dividing up some part of Africa, when neither party was familiar with either the region or the people they were impacting on. For instance, a river unexplored by Europeans is the agreed boundary and one power has the right to any islands in this river, even though neither power is sure there are any.

To say more requires both philosophy of language and metaphysics, both of which are controversial. Here is a sketch, based on the theory that perception is a relation to a universal, which is instantiated if the perception is veridical (Forrest 2005). Readers may substitute their preferred theory. To imagine is to stand in a certain relation to a universal that need not have been perceived but must be related to ones that have been using some short list of relations - relations that we also comprehend. ${ }^{12}$ I shall use the term 'comprehend' in a narrow sense,

${ }^{12}$ The least controversial of which is conjunction. These may well be innate in that no experience is required of these relations. 
according to which we comprehend what we are able to imagine. Using either language or some pre-linguistic way of thinking, we can think about the universals we comprehend as well as ones that we do not. ${ }^{13}$ The latter (which perhaps need not exist) are formed in ways that do not enable us to imagine. For instance, we comprehend causation and we comprehend coming into existence, so we can talk meaningfully about a cause of all that comes into existence, but without comprehension.

Anthropomorphites, then, should not be accused of claiming to comprehend God, merely to be able to describe God as an agent of unlimited power.

\section{IV. 'YOU KANT SAY THAT!'}

I have never met anyone who is prepared to defend the arguments that Kant actually relies on in (either edition of) the Critique of Pure Reason. Nonetheless it is widely supposed that Kant has undermined both metaphysics and natural theology. I suspect this is a case of 'Non! Je ne regrette rien. ${ }^{14}$ It takes courage to study a difficult author only to declare it a waste of time.

In this situation I challenge would-be defenders of Kant to state arguments against anthropomorphic theism that they are prepared to defend from objections. In addition I consider what it would be like to be persuaded by Kant and so I distinguish shallow from deep Kantianism.

By shallow Kantianism I mean a certain way of putting scare quotes around 'knowledge' and 'truth', to mean what we naturally but, it is said, mistakenly tend to call knowledge and truth, respectively. By deep Kantianism I mean a theory of truth as a triadic relation between truthbearers, truth-makers ('things in themselves') and truth-mediators, where the last are dependent on our nature as human beings. Deep Kantians say that truth is relative to truth-mediators in a way that anti-Kantians would consider benighted. Thus, suppose that the best way of understanding

${ }^{13}$ Maybe thinking about is identity in this case. That is, the referring expression in the language of thought is the universal it is about. (I follow Richard Sylvan in using the phrase 'is about' rather than 'refers to' because it is widely assumed that we cannot refer to what does not exist.)

${ }^{14}$ Continental philosophers might like to take Edith Piaf's song as their anthem. 
things is a theory that entails the existence of an X or some Xs (Xs might be electrons, say, or, more pertinently the anthropomorphic God). Then the natural tendency is to believe that there exists an X, relying on an inference to the best explanation. And we may be explicit and say that the natural tendency is to say both that we know there exists an X and that 'There exists an $\mathrm{X}$ ' is true. As an anti-Kantian, I agree, apart from some scruples about calling belief knowledge when sane intelligent people disagree with me. Shallow Kantians, however, are sceptics and deny the capacity of our natural belief-forming tendencies to arrive at truth on such theoretical topics. Shallow Kantians might, like Vaihinger with his philosophy of 'als ob,' live their lives as if there are Xs, and expect it to remain as if there are Xs (1968). This is much the same as 'accepting' that there are Xs in van Fraassen's sense of accepting a theory while suspending judgement as to its truth (1980).

There are several reasons for rejecting shallow Kantianism. The first is that if applied universally it is self-limiting. For it then requires suspense of judgement about shallow Kantianism itself. The second is that the case for shallow Kantianism concerning anthropomorphic theism is weaker than that concerning the theoretical entities of science. For consider Larry Laudan's pessimistic induction: most scientific theories have been shown false so current ones are more likely than not also false (Laudan 1981). We may say that, for instance, Newton's theory of gravity is false but it is mostly as if it is correct. The nearest thing to a pessimistic induction in theology is that over the millennia the number of gods believed in has declined to one and the next step is zero. You might as well argue that because microscopes have been invented that enable us to see smaller and smaller things we will soon be able to see things of zero diameter.

The third, and I think, most serious problem with the application of shallow Kantianism to anthropomorphic theism concerns its extension to other religious beliefs notably the future self-revelation by God. I call this the eschatological objection. On the assumption that it is as if there is an anthropomorphic God then the future divine self-revelation will be as if the anthropomorphic God is revealed. But that is, according to shallow Kantians, concealment not revelation.

Deep Kantians agree with anti-Kantians that we should believe in accordance with our natural tendencies, but - as a result of the systematic application of these tendencies, they say - truth isn't what 
we 'naively' thought. ${ }^{15}$ In that case we should believe anthropomorphic theism to be true, although not 'naively' true, and hence that there exists an anthropomorphic God.

The only difficulty I envisage given deep Kantianism is a renewed charge of idolatry on the grounds that the anthropomorphic God is less worthy of worship than an unknowable God-in-Itself. My response is that worship is an attitude of unconditional trust and obedience, and that these attitudes are just as much to things-as-they-are-related-to-us as are beliefs. It is not as if we are to change epistemic gear when it comes to religion. Nothing more is required of beliefs than truth, no matter what truth turns out to be.

\section{V. 'SHALL OLD AQUINAS BE FORGOT?'}

There was a dispute between those such as Duns Scotus who held that we are able to say some positive things of God and of human beings in a straightforwardly univocal fashion and others, such as Thomas Aquinas, who held that words such as 'good' applied by analogy to God and to humans. This was largely because Aquinas held a strong doctrine of divine simplicity according to which the divine attributes are all identical to God.

First I shall rebut the thesis that predicates such as 'has causal power,' 'has knowledge' and 'is morally good' apply analogically to God. Then I shall undermine the reasons for proposing that thesis.

If we apply analogy in Aristotle's 'pros hen' sense to talking about such a God then we might say that God has causal power, knowledge and goodness in the sense that human causal power, human knowledge, and human goodness are signs of God, just as urine is called (un)healthy if it

${ }^{15}$ I am supposing a broadly Reidian epistemology based upon trust in the ways of reasoning we tend to use prior to critical reflection. This trust may be defeated using other natural ways of reasoning. The outcome of this process of self-correction cannot be determined by over-arching principles because these principles would themselves be the products of such reasoning. I am conceding that someone might arrive at a Kantian position as a result of this process of self-correction. I suspect, however, that Kantianism results instead from excessive concern with knowledge. 
is a sign of (poor) health. (Aquinas uses this example as well as Aristotle, apparently endorsing a sign account of analogy. $)^{16}$

To apply predicate $\mathrm{X}$ by analogy to $\mathrm{b}$ in this sense might but should not be understood minimally as saying that $\mathrm{b}$ brings about Xs. For that would permit any number of silly analogies in the human case: the clapper is by analogy the clap, and so on. Moreover, if we do understand analogy in this minimal fashion it also follows that God is by analogy bad as well as good. For some intrinsically bad things, such as moderate suffering, seem to be part of the divine plan and so are caused by God. And that is not the intention of those who tell us that predicates apply to God by analogy. Now it is tempting to respond that God creates with moderate suffering as part of the design plan, but it is for a good purpose. I agree but that it is to go beyond the minimal account of analogy.

As its rather complex history shows, the theory of analogy asserts more than that God causes various effects. Given the current use of the word 'analogy' it is no surprise that resemblance may be used in the analysis of analogy. This can occur in one of two ways. We might say that the effects of God are like the effects of an agent of a certain kind. Or we might say that God Itself is like an agent of a certain kind. The first amounts to saying it is as if there is an anthropomorphic God, and so turns into shallow Kantianism restricted to God. To go where scholars fear to tread, I speculate that Kant came to say of everything what he already as a Lutheran pietist said of God, or even that Kantianism is what you get when you cross pantheism with pietism. I have already explained why I reject shallow Kantianism and the eschatological objection holds against the as if anthropomorphic theory.

Analogy in its current ordinary sense would have it that God resembles the anthropomorphic God. This is interesting because it raises the question of whether overall resemblance is unanalysable or, as I claim, it holds in virtue of respects of resemblance. In the latter case, predicates corresponding to those respects are predicated univocally of God and human beings. To treat resemblance as unanalysable is a Wittgensteinian thesis. The chief reason for rejecting it is that (1) we do distinguish respects of resemblance and (2) overall resemblance may be analysed in terms of a combination of respects of resemblance and pragmatic

\footnotetext{
${ }^{16}$ For a discussion of medieval theories of analogy see (Ashworth 2009.)
} 
considerations, but attempts to analyse respects of resemblance in terms of overall resemblance and pragmatic considerations fail.

Let us now consider the motivation for analogical predication, from the strong thesis of divine simplicity. I submit the case for divine simplicity is only a case for the weaker thesis that the first cause has no parts.

If God has parts, as it might be if the three Divine Persons are themselves gods, then, it is said, God depends on the parts and so is 'ab aliud,' contrary to being the first cause. Again if God has parts then, it might be said, some of these parts could exist without the others, so God would not be a necessary being, as is required for a first cause. Neither of these arguments is beyond criticism, but that is not my present concern, which is the application of them to properties. If properties are treated as particulars, as in the unhappily named 'trope' theory of D. C. Williams (1953) then they are indeed parts of the things that have them. And Aquinas's position may well be a 'trope' theory. But if you are a realist about universals, like Duns Scotus, or a nominalist, like William of Ockham, there is no reason to assimilate properties to parts. Nonetheless there is a genuine problem here. There is no necessary connection between moral goodness on the one hand and power and knowledge on the other. So to hypothesise that unlimited power and knowledge entails goodness is an extravagant hypothesis, unlike the plausible hypothesis that unlimited power requires unlimited knowledge. I have argued elsewhere that goodness is applied to the first cause in an analogical sense only, but that God acquires literal goodness. Putting that to one side I see no reason why the first cause should not be an agent of unlimited power and knowledge.

\section{WHAT THOSE GARRULOUS MYSTICS SAY ABOUT THE INEFFABLE}

I ask the mystic who claims to have experienced (being one with?) God the question, 'What make you think it was God?' It is not possible to experience lack of all limitations. How can we tell the difference between a god (angel) with power over this universe and a God with power over all universes? The mystic runs a more serious risk of idolatry than the anthropomorphite. 
To have any assurance that what is experienced is indeed divine the mystic requires a conception of God instead of being the sort of apophat who rejects any such conception. I have already argued against the apophatic conception. I conclude that only by being anthropomorphites may mystics reasonably say that what they experience is so much more than merely having a true description of God.

\section{ANTHROPOMORPHISM AND ANTI-THEODICY ${ }^{17}$}

By anti-theodicy I mean the position that theodicy ('justifying God's ways to Man'), whether intellectually successful or not, is a morally obnoxious enterprise (see Trakakis 2008). As I understand it, anti-theodicy is based on the accusation that the theodicist assumes that God is part of our moral community, and that given this piece of anthropomorphism it is both absurd and offensive to offer the usual theodicies such as the free will defence. ${ }^{18}$ My response is that there is more than one moral community: there is the community of all agents, to which God belongs, and there is a community of frail, cognitively limited, agents, to which God does not belong. Relative to the first community we should, albeit cautiously, stand in judgment on God, whom I find innocent. Relative to the second community it would be blasphemous to do so.

The anthropomorphic God is an agent, as we are, but unlike us in not being limited in knowledge. Our limitations in this regard explain why for human beings the ends do not always justify the means. For human beings to act so as to maximize expected utility given their beliefs about the future is for them 'to play God'. The anti-theodicist is in effect accusing the anthropomorphic God of playing God.

\footnotetext{
${ }^{17}$ See (Forrest 2010) for a more detailed criticism of anti-theodicy.

${ }^{18}$ In analytic philosophy of religion it is common to follow Plantinga and distinguish a defence from a theodicy, the former being merely intended to establish the consistency of a good God creating a universe with many and grievous evils. The distinction is not important here.
} 


\section{CONCLUSION}

The current intellectual disdain for anthropomorphic theism is, I have argued, without any basis. It strikes me as 'sour grapes': prematurely despairing of the reasonableness of anthropomorphic theism, the intellectual pretends that this is a crude conception of the divine.

\section{BIBLIOGRAPHY}

Ashworth, Jennifer, (2009), 'Medieval Theories of Analogy', The Stanford Encyclopedia of Philosophy (Fall 2009 Edition), Edward N. Zalta (ed.), URL $=\langle\mathrm{http} / / /$ plato.stanford.edu/archives/fall2009/entries/analogy-medieval $/>$.

Bird, Alexander and Tobin, Emma, 'Natural Kinds' (2010), The Stanford Encyclopedia of Philosophy (Summer 2010 Edition), Edward N. Zalta (ed.), URL $=<$ http://plato.stanford.edu/archives/sum2010/entries/natural-kinds/ $>$. Bishop, John (2007), Believing by Faith, Oxford: Oxford University Press.

Caputo, John (1997), The Prayers and Tears of Jacques Derrida: Religion without Religion, Bloomington: Indiana University Press.

Forrest, Peter (2005), 'Universals as Sense-data,' Philosophy and Phenomenological Research, 71: 622-31.

Forrest, Peter (2007), Developmental Theism: From Pure Will to Unconditional Love, Oxford: Oxford University Press.

Forrest, Peter (2010), 'Why Richard Swinburne Won't 'Rot in Hell': A Defence of Tough-Minded Theodicy', Sophia 49.

Gallie, W. B., (1956), 'Essentially Contested Concepts', Proceedings of the Aristotelian Society 167.

Gleeson, Andrew (2010), 'The Power of God', Sophia 49 :603-616.

Kripke, Saul, (1980) Naming and Necessity, Oxford: Basil Blackwell.

Kyburg Jnr., Henry E. (1974), The Logical Foundations of Statistical Inference, Dordrecht: Reidel.

Laudan, Larry (1981), 'A Confutation of Convergent Realism', Philosophy of Science, 48: 19-49.

Newman, John Henry (1903), An Essay in Aid of a Grammar of Assent, (9th ed.) Longmans and Green.

Phillips, D. Z. (1995) Faith After Foundationalism: Critiques and Alternatives, Westview Press.

Priest, Graham (1995), Beyond the Limits of Thought, Cambridge: Cambridge University Press. 
Putnam, Hilary (1973), 'Meaning and Reference,' Journal of Philosophy 70: 699711.

Rawls, John (1971), A Theory of Justice, Oxford: Oxford University Press. Trakakis, Nick (2008), The End of Philosophy of Religion, Continuum.

Vaihinger, Hans (1968), The Philosophy of 'As If': A System of the Theoretical, Practical and Religious Fictions of Mankind, Translated by C. K. Ogden, New York: Barnes and Noble.

Van Fraassen, Bas C. (1980), The Scientific Image, Oxford: Clarendon Press.

Williams, D. C. (1953), 'The Elements of Being', Review of Metaphysics, 7: 3-18, 171-192.

Wolterstorff, Nicholas (2010), 'Alston on Aquinas on theological predication,' ch 6 of Inquiring about God: Selected Essays, Volume 1, ed. Terence Cuneo, Cambridge: Cambridge University Press. 